\title{
ОСОБЛИВОСТІ ВІДШКОДУВАННЯ ШКОДИ, ЗАВДАНОЇ НЕПОВНОЛІТНЬОЮ ОСОБОЮ
}

\begin{abstract}
Анотація. Сьогодні, в умовах стрімкого розвитку суспільства, ми можемо бачити проблему невідповідності чинного законодавства реаліям, які $е$ наслідком постійних змін і в яких ми живемо. Зокрема, з огляду на стрімкий розвиток нашої молоді, майбутнього покоління або ж покоління «Z», можемо зробити висновок про те, що ті стандарти, на основі яких писалося наше законодавство, а саме цивільне законодавство, є вже застарілим. Так, одніею з застарілих норм $е$ норма щодо відшкодування шкоди, завданої неповнолітніми особами. При написані статті було зроблено аналіз наукових робіт багатьох вчених, а також зарубіжного законодавства. Дослідження ряду нормативно-правових актів зарубіжних країн світу показало нам, як визначаеться цивільно-правова відповідальність, зокрема, в Грузії та Німеччині. На підставі проведеного дослідження було запропоновано внести зміни до чинного Цивільного кодексу України.
\end{abstract}

Ключові слова: делікт, цивільно-правова відповідальність, відшкодування шкоди, неповнолітні особи.

Grabovska Hanna, Boiko Oleksii National Aviation University

\section{FEATURES OF COMPENSATION FOR DAMAGE CAUSED BY A MINOR}

Summary. Today, in the conditions of rapid development of society, we can see the problem of inconsistency of current legislation with the realities that are the result of constant change and in which we live. In particular, given the rapid development of our youth, the future generation or generation "Z", we can conclude that the standards based on which our legislation was written, namely civil law, are already outdated. Thus, one of the obsolete norms is the norm on compensation for damage caused by minors. In Ukraine, the age at which a person becomes tort is 14 years. Georgian and German law define different ages of tort: 7 years in German civil law and 10 years in Georgian civil code, respectively. Nevertheless, they have one thing in common - determining the necessary condition for liability for damage caused by a minor - the presence of awareness. Compensation for damage is generally related to consciousness and awareness. Thus, based on the above, it is possible to draw a conclusion about the unresolved issue of the need to change the age of tort from 14 to 7 years. If a person is able to independently carry out mental processes that result in legal actions (both legal and illegal) - this means the ability of a person to realize the meaning and possible consequences of their actions. The fairness of tort should be proportionate to the person's ability to be aware of his actions. When writing the article, an analysis of the scientific works of many scientists, as well as foreign legislation. A study of a number of regulations of foreign countries has shown us how to determine civil liability, in particular, in Georgia and Germany. Based on the research, a number of conclusions were made, in particular: First, taking into account the acceleration, ie the acceleration of the rate of age development of children and adolescents compared to previous generations, it is necessary to make appropriate changes to existing legislation in order to take into account all the features of age categories. Secondly, the necessary changes should be made based on the correlation of acceleration and psychological development of the person, ie choose the age when the person should be aware of their actions and the possible consequences of such actions.

Keywords: delict, civil liability, compensation for damage, minors.

Ц ивільно-правова відповідальність передбачається нормами чинного українського законодавства. Як відомо, нерідко значна шкода особі, а також майну громадян та юридичних осіб завдається неправомірними діями громадян, які не досягли повноліття, тобто тими особами, які не володіють повною цивільною дієздатністю (виключенням є особи, які набули повною цивільної дієздатності до настання повноліття: у разі реєстращії шлюбу фрізичної особи, яка не досягла повноліття; якщо особа, яка досягла шістнадцятирічного віку працюе за трудовим договором, а також неповнолітній особі, яка записана матір'ю або батьком дитини; якщо особа, яка досягла шістнадцятирічного віку і бажає займатися підприемницькою діяльністю) але вже володіють деліктоздатністю - здатністю нести цивільно-правову відповідальність за шкоду, заподіяну протиправними діями, що виражаються у здатності суб'єкта самостійно усвідомлювати свій вчинок i його шкідливі результати, відповідати за свої протиправні дії і нести за них відповідальність. Правила щодо відшкодування шкоди, завданої неповнолітньою особою, закріплені в нормах ст. ст. 1179 та 1180 Цивільного кодексу України.

Постановка проблеми. Сьогодні в світі відбувається все більше і більше змін: наукових, інформаційних, технічних та технологічних, а також, що є дійсно важливим, біологічних. Нове покоління завдяки швидкому розвитку оточуючого світу дорослішає швидше, аніж раніше. Але, як це часто буває, законодавство не встигає за швидкими змінами, а отже деякі його норми стають неактуальним, або ж вирішують питання виходячи із застарілих стандартів. Однією з таких норм є норма щодо відшкодування шкоди, завданої неповнолітньою особою.

Аналіз останніх досліджень і публікацій. Дослідження цивільно-правової відповідальності за завдану шкоду була предметом наукових досліджень таких науковців: С.Н. Братуся, О.Й.Брагінського, А.М. Белякової, В.С. Венедикто- 
ва, В.Г. Верднікова, В.В. Глянцева, С.С. Донцова, Н.M. Сршової, О.А. Красавчикова, Г.К. Матвеєва, М.Я. Мариніної та ін. Проблемам цивільно-правової відповідальності неповнолітніх осіб присвячені роботи таких науковців як: Т.С. Криворучко, Я.М Шевченко, Е.А. Флейшиц, Санфилиппо Чезаре. Незважаючи на значну кількість досліджень, проблеми цивільно-правової відповідальності за завдану шкоду неповнолітніми особами, не втратили своеї актуальності.

Цілі статті. Метою цієї статті є дослідження особливостей відшкодування шкоди завданої неповнолітньою особою, загальний аналіз законодавства, історичних аспектів та міжнародної практики. Головною ціллю статті є узагальнення міжнародної практики стосовно відшкодування шкоди, завданої неповнолітньою особою та пропозиції щодо внесення змін до чинного в Україні законодавства, з метою створення працюючого та справедливого підѓрунтя задля забезпечення повної реалізації відшкодування шкоди, завданої неповнолітньою особою.

Виклад основного матеріалу. Відшкодування шкоди, заподіяної неповнолітніми особами, здійснюеться на таких підставах. Частина 1 ст. 1179 ЦК визначае, що неповнолітня особа відповідае за заподіяну нею шкоду самостійно на загальних підставах [1]. Це означае, що в разі заподіяння шкоди неповнолітньою особою мають бути досліджені всі умови покладення на заподіювача шкоди обов'язку таку шкоду відшкодувати. До таких умов належать: протиправна поведінка неповнолітнього, яка виражається в порушенні ним суб'єктивних прав потерпілого, причинний зв’язок між діяльністю неповнолітнього та ії̈ наслідками, а також вина неповнолітнього заподіювача шкоди. Якщо закон покладає на заподіювача шкоди обов'язок іï відшкодування незалежно від вини (наприклад, в разі заподіяння шкоди джерелом підвищеної небезпеки), вина неповнолітнього також не враховуеться. Якщо шкода заподіяна неповнолітнім під час виконання ним трудових обов'язків, обов'язок по ії̈ відшкодуванню покладається на юридичну або фізичну особу-роботодавця неповнолітнього (ст. 1172). Така позиція законодавця зумовлена тим, що неповнолітній вже не тільки взмозі зрозуміти значення своїх дій і дій третіх осіб, а й здатний керувати ними, усвідомлювати їх суспільну оцінку.

Проте, майнова відповідальність неповнолітніх мае свої специфічні риси, які зумовлені суб'ектом такої відповідальності, - особою, яка не досягла 18 років.

Така специфіка закріплена у ч. 2 ст. 1179 ЦК України, відповідно до якої у разі відсутності в неповнолітньої особи майна, достатнього для відшкодування заподіяної нею шкоди, ця шкода відшкодовуеться в частці, якої не вистачае, або в повному обсязі ї̈ батьками (усиновлювачами) або піклувальником, якщо вони не доведуть, що шкода була заподіяна не з їхньої вини. Якщо неповнолітня особа перебувала в закладі, який за законом здійснюе щодо неї функції піклувальника, цей заклад зобов'язаний відшкодувати шкоду в частці, якої не вистачае, або в повному обсязі, якщо він не доведе, що шкода була заподіяна не 3 його вини. Батьки неповнолітнього, позбавлені батьківських прав, несуть відповідальність за нормами ст. 1183 ЦК України також, як і батьки малолітнього, позбавлені батьківських прав.

За своїм характером відповідальність батьків (усиновлювачів) і піклувальників неповнолітнього є додатковою або субсидіарною. Ї̈ суть полягае в тому, що вищезазначені особи відповідають перед потерпілим у тій частині, в якій не можуть відповідати самі неповнолітні через відсутність у них майна, достатнього для відшкодування шкоди [2].

Діездатність та деліктоздатність тісно пов'язані між собою в питані відшкодування шкоди, завданої неповнолітньою особою і об'еднуе їх одне - усвідомлення особою своїх дій. Іншими словами, відшкодування шкоди загалом пов'язано зі свідомістю та усвідомленням.

Свідомість являе собою суб'єктивне розуміння свого «Я». Коли дитина з'являеться на світ, у неї ще немае свідомості, вона виникае пізніше, приблизно до року, коли дитина починае розуміти, що вона це вона. Свідомість не з'являеться сама по собі, її виникнення напряму пов'язане 3 оточуючим світом, з суспільством. Усвідомленість - це наступний етап свідомості, коли людина вже може прийняти відповідальність за себе та за свое життя.

Ми часто чуемо, як люди літнього віку люблять повторювати: «в наш час ми такими не були». Вони мають ращію - кожне покоління відрізняеться від попереднього. Вчені переконані: сьогодні діти дорослішають швидше за своїх батьків.

Перші зафріксовані спостереження щодо швидкості розвитку людини в молодшому віщі були зроблені в першій половині XX століття. Акселерація - прискорення індивідуального розвитку організмів порівняно з розвитком у попередні історичні періоди. В антропології - це прискорення соматичного, фізичного та психічного розвитку людини (найчастіше - у дитячі та юнацькі роки). Явище акселерації спостерігаеться вже понад сто років. За даними медиків і фрізіологів, сучасні діти та підлітки більш розвиненні фізично й розумово, ніж їхні ровесники [3].

3 цим пов'язано ряд несподіваних наслідків. Наприклад, в країнах Європи та Північної Америки вік вступу в шлюб змінився на 5-7 років, що пояснюеться більш раннім віком початку статевого життя у підлітків і більшою свободою дії в зв'язку з цим.

Важко собі уявити, щоб такі зміни не вплинули на психічний розвиток нових поколінь. Маршалл Маклюен, який займався теорією комунікації, відзначав, що в зв'язку з небувалими обсягами інформації, які в умовах сучасного світу обробляе людський мозок, швидкість мислення людей в розвинених країнах за останне сторіччя подвоїлася і продовжує рости. У побутовому плані цей процес очевидно спостерігаеться на дітях, народжених в цифрову епоху: вміння користуватися складною комп'ютерною технікою розвивається у них паралельно з розвитком мовних навичок, а іноді і випереджаючи останні.

3 огляду на зміни в розвитку неповнолітніх осіб, можна говорити про необхідність зниження віку деліктоздатності. Так, наприклад, статтею 994 цивільного кодексу Грузії зазначено, що особа у віщі більше 10 років, но ще неповнолітня, несе відповідальність за шкоду, завдану нею іншим особам, окрім випадків, коли при заподіянні шкоди вона не могла розуміти значення своїх дій [4]. 
Окрім деліктоздатності, яка наступає 3 десятирічного віку, цією статтею визначену іншу важливу умову - усвідомлення дій.

Відповідно до абзацу $2 \S 828$ Німецького цивільного уложення, особа, якій виповнилось сім років, однак, яка ще не досягнула вісімнадцятирічного віку, не відповідає за шкоду, завдану іншій особі, якщо вона при скоєнні дій, які заподіяли шкоду, не володіла розумінням, необхідним для усвідомлення своєї відповідальності [5].

Обидва приклади визначають різний вік набуття деліктоздатності: 7 років в німецьокму цивільному уложенні та відповідно 10 років в цивільному кодексі Грузії. Але вони мають спільну рису - визначення необхідної умови для настання відповідальності за заподіяну шкоду неповнолітньою особою - наявність усвідомлення.

Таким чином, настання деліктоздатності за Німецьким цивільним кодексом пов’язуються із двома фрактами: досягнення певногу віку та здатністю неповнолітнього до усвідомлення значення своїх дій; у такій позиції простежуеться рецепція ідея римських юристів про те, що неповнолітня особа, яка досягла семирічного віку, відповідає за Аквілієвим законом, оскільки несе відповідальність і за крадіжку; і це правильно, якщо вона вже здатна до вчинення протиправних дій. При цьму малолітня особа, тобто особа, яка не досягла семирічного віку, за римським правом не володіє деліктоздатністю [6].

Отже, на підставі вищевикладеного можна зробити винсновок про невирішеність питання щодо необхідністі зміни віку деліктоздатності з 14 до 7 років. Якщо особа здатна самостійно здійснювати психічні процеси, наслідком яких $€$ юридичні дії (як правомірні, так і неправомірні) - це означае здатність особи усвідомлювати значення та можливі наслідки своїх дій.

Не завжди правильним є пов'язувати виникнення, зміну чи припинення правовідносин лише із досягненням особою конкретного віку. За Сімейним кодексом України, наприклад, усвідомлення своїх дій визнається за дітьми, які досягли 7 або 10 років (ст. 148 та ст. 160 Сімейного кодексу України), а також у випадках, коли вони можуть висловлювати свою думку (ч. 2 ст. $171 \mathrm{Ci}$ мейного кодексу України) [7].

Радянська література вік виникнення деліктоздатності пояснювала матеріальною спроможністю відшкодовувати завдану шкоду, але досягнення особою чотирнадцятирічного віку не завжди означає повне усвідомлення та розу- міння нею своїх дій, більше того, часто фрактичне матеріальне становище особи може залишатися таким самим, яким воно було до досягнення нею чотирнадцятирічного віку [8] .

Справедливість деліктоздатності повинна бути пропорційною можливості особи усвідомлювати свої дії. Як зазначала Я.М. Шевченко, сама можливість визнання неповнолітніх винними пов'язана 3 інтелектуальними та вольовим аспектами свідомості, з можливістю усвідомлювати негативний і протиправний характер своїх дій, 3 можливістю передбачити наслідки своїх дій, з можливістю самовладання, утримання від певних дій чи спрямування дій на певні завдання; робити правильну оцінку оточуючих нас явищ і відповідно на них реагувати [9].

Таким чином, ми маємо два шляхи в питанні необхідності зміни застарілого законодавства: перший і найлегший - змінити вік деліктоздатності 314 років до 10 років; другий - залишити індивідуальне визначення усвідомленості своїх дій у конкретної особи в кожній новій справі.

Обираючи другий шлях визначення усвідомленості ми маємо ризик зіткнутися 3 проблемою ощіночних суджень суддів або необхідності в залучені кожного разу експерта для визначення того, чи усвідомлювала особа, що вона робить i які можуть бути наслідки, чи ні. Тому оптимальним буде обрання одразу двох цих шляхів.

Висновки дослідження i перспективи. Отже, підсумовуючи все вищевикладене можна зробити наступні висновки:

По-перше, враховуючи акселеращію, тобто прискорення темпів вікового розвитку дітей і підлітків порівняно 3 попередніми поколіннями, необхідно внести відповідні зміни до діючого законодавства, з метою врахування всіх особливостей вікових категорій.

По-друге, необхідні зміни треба вносити виходячи також із кореляції акселерації та психологічного розвитку особи, тобто обрати той віковий період, коли особа вже повинна усвідомлювати свої дії та можливі наслідки від таких дій.

Таким чином, базуючись на наведених висновках, пропонуемо внести зміни до Цивільного кодексу України, та викласти ч. 1 ст. 1179 наступним чином:

«1. Неповнолітня особа (у віщі від десяти до вісімнадцяти років) відповідає за завдану нею шкоду самостійно на загальних підставах, якщо вона при скоєнні дій, які заподіяли шкоду, усвідомлювала цю дії, можливі наслідки та відповідальність».

\section{Список літератури:}

1. Цивільний кодекс України : Закон України від 16 січня 2003 р. № 435-IV // Відомості Верховної Ради України. 2003. № 40-44. Ст. 356.

2. Дзера О. В. Цивільне право України: Особлива частина : підручник / за ред. Дзери О. В., Кузнєцової Н. С. 3-є вид., перероб. і доп. Київ : Юрінком Інтер, 2010. 1176 с.

3. Криворучко Т. С. Гигиеническое значение изменений в биологии развития человека: (Причины и значение акселерации развития) / Т. С. Криворучко. Кишенев, 1979; Морфо-фрункциональное проявление акселерации развития детского организма Москва, 1979; Зарандия М. И. Закономерность акселерации развития ребенка. Тбилиси, 1985.

4. Гражданский кодекс Грузии. Принят 26 июня 1997. Введен в действие с 25 ноября 1997 года (с поправками и изменениями на 26 ноября 2001 года).

5. Німецьке цивільне уложення. Прийняте 18.01.1896, набрало чинності з 01.01.1900.

6. Санфилиппо Чезаре. Курс римского частного права : учебн. / Санфилиппо Чезаре ; [под ред. Д. В. Дождева]. Москва : БЕК, 2002. 400 с.

7. Сімейний кодекс України : Закон України від 10 січня 2002 № 2947-III // Відомості Верховної Ради України. 2002. № 21-22. Ст. 135. 
8. Флейшиц Е. А. Обязательства из причинения вреда и из неосновательного обогащения. Москва : Гос. Изд-во юрид. лит., 1951. 239 с.

9. Шевченко Я. М. Характеристика особливостей психіки неповнолітніх та їх вияв при вчиненні майнових правопорушень. Діездатність і осудність дітей. Вісник Київського університету. 1962. № 5. Вип. 1. Серія економіки та права. С. 95-98.

\section{References:}

1. Cyvilnyj kodeks Ukrayiny (2003). Vidomosti Verxovnoyi Rady Ukrayiny.

2. Dzera O. V. (2010) Cyvilne pravo Ukrayiny [Osoblyva chastyna]: pidruchnyk. Kyiv: Yurinkom Inter, p. 1176.

3. Kryvoruchko T. S. (1979). Gygyenycheskoe znachenye yzmenenyj v byologyy razvytyya cheloveka [Prychyny y znachenye akseleracyy razvytyya]. Kyshenev. Morfo-funkcyonalnoe proyavlenye akseleracyy razvytyya detskogo organyzma (1979) Moskva. Zarandyya M. Y. Zakonomernost akseleracyy razvytyya rebenka (1985). Tbylysy.

4. Grazhdanskyj kodeks Gruzyy (1997). Prinyat 26 iyunya 1997. Vveden v deystvie s 25 noyabrya 1997 goda (s popravkami i izmeneniyami na 26 noyabrya 2001 goda).

5. Nimeczke cyvilne ulozhennya (1896). Pryiniate 18.01.1896, nabralo chynnosti z 01.01.1900.

6. Sanfylyppo Chezare (2002). Kurs rymskogo chastnogo prava. Moscow: BEK, p. 400.

7. Simejnyj kodeks Ukrayiny (2002). Vidomosti Verxovnoyi Rady Ukrayiny.

8. Flejshycz E. A. (1951) Obyazatelstva yz prychynenyya vreda y yz neosnovatelnogo obogashhenyya. Moscow: Gos. Yzdvo yuryd. lyt., p. 239.

9. Shevchenko Ya.M. (1962) Xarakterystyka osoblyvostej psyxiky nepovnolitnix ta yix vyyav pry vchynenni majnovyx pravoporushen [Diyezdatnist i osudnist ditej]. Visnyk Kyyivskogo Universytetu, pp. 95-98. 